\title{
Development and survival of Neoleucinodes elegantalis (Lepidoptera: Crambidae) on wild and cultivated solanaceae
}

\author{
Carla Pedroso de Moraes ${ }^{1}$, Luís Amilton Foerster ${ }^{2 *}$ (i) \\ ${ }^{1}$ Universidade Tuiuti do Paraná, Curitiba, PR, Brasil. \\ ${ }^{2}$ Universidade Federal do Paraná, Departamento de Zoologia, Curitiba, PR, Brasil.
}

\section{A R T I C L E I N F O}

\section{Article history:}

Received 02 December 2020

Accepted 09 September 2021

Available online 09 August 2021

Associate Editor: Adeney Bueno

\section{Keywords:}

Alternative hosts

Biology

Behavior

Small tomato fruit borer

Invasion risk

Eggplant

Solanum lycopersicum

\begin{abstract}
A B S T R A C T
The small tomato fruit borer Neoleucinodes elegantalis is a pest of wild and cultivated solanaceous of economic importance, such as tomatoes, eggplant, peppers and scarlet eggplant. We compared the development, survival and reproduction of $N$. elegantalis in cultivated and wild Solanaceae as alternative hosts in the absence of tomato plants in the field. The development time was significantly affected by the host plant and was longer in larvae feeding on eggplant. Survival of the immature stages was higher in larvae fed on tomato and eggplant, although the development cycle was completed in all hosts. Fecundity was also influenced by the host plant and was lower when the larvae fed on scarlet eggplant and the wild solanaceae Solanum paniculatum (jurubeba). The net reproductive rate was lower in jurubeba and the intrinsic growth rate was higher in Solanum sp. The results show that both wild Solanum species can act as alternative hosts for $N$. elegantalis during the intercropping of tomato in winter and autumn and may thus act as larval reservoirs for infestations on cultivated species. The large number of hosts able to sustain the development of $N$. elegantalis is another factor, together with world's climate changes, to increase the invasive potential of $N$. elegantalis into tomato-producing countries.
\end{abstract}

\section{Introduction}

The small tomato fruit borer, Neoleucinodes elegantalis (Lepidoptera: Crambidae) is an oligophagous pest that attacks fruits of the family Solanaceae. It is widely distributed in Central and South America (EPPO, 2015), infesting most solanaceous of economic importance, such as tomato, eggplant, pepper and scarlet eggplant (Picanço et al., 1997; EPPO, 2015). Economic losses in general are more expressive in tomato crops (Picanço et al., 1998; Arcanjo et al., 2021) because the damage is caused directly to the fruits (Silva et al., 2017b). The life cycle of $N$. elegantalis was studied in fruits of tomato, eggplant and "naranjilla", Solanum quitoense(Marcano, 1991a, 1991b; Moraes and Foerster, 2014; Noboa and Viera, 2020) under controlled conditions of temperature and relative humidity. Eggs are laid on young tomato fruits $(0.5-4 \mathrm{~cm}$; in diameter); hatching generally occurs in about five days and in less than two hours after hatching, larvae penetrate the fruits (Silva et al., 2020). The short time between larval eclosion and its penetration into the fruits limits the effectiveness of insecticides and biological control agents (Blackmer et al., 2001) making its management impracticable and thus leading to severe tomato production losses (Picanço et al., 2007; Silva et al., 2019a, 2020).

According to Silva et al. (2017a) N. elegantalis is a threat to all tomato-producing areas in the world and although it has not been found in Europe, it is recommended as a quarantine pest A1 (EPPO, 2015). Besides climatic conditions (Silva et al., 2017a, 2020), the polyphagous behavior of pests favors invasive species to establish and spread into new regions (Barbuceanu et al., 2015; Goergen et al., 2016; Camerini, 2017). Like the tomato leafminer Tuta absoluta(Meyrick) (Lepidoptera: Gelechiidae), once initially established, it can rapidly spread to growing areas with similar climatic conditions of its current area of distribution (Desneux et al., 2010, 2011). At present, T. absoluta has spread to various European, Asian and African countries (Biondi et al., 2018; Fand et al., 2020).

\footnotetext{
*Corresponding author.

E-mail: foerster@ufpr.br (L.A. Foerster).
} 
Due to the oligophagous habit of $N$. elegantalis on solanaceous plants (Díaz-Montilla et al., 2013), some of these wild and introduced species are potential hosts of the pest in the field. Besides cultivated species, wild solanaceous fruits are also reported as hosts of $N$. elegantalis (Zucchi et al., 1993; Díaz-Montilla et al., 2013; EPPO, 2015), These plants can be used as a refuge by $N$. elegantalis, allowing its survival when cultivated species are not available during the tomato offseason, or when agricultural practices are carried out during cultivation, such as after insecticide applications (Fitt, 1989).

There is no information in the literature on the role of wild solanaceous plants, on the biological traits of the small tomato fruit borer. Alternative host plants can sustain the growth and reproduction of the pest when the preferred host is not available in the field. In order to evaluate the influence of different larval foods, we compared the development, reproduction and longevity of $N$. elegantalis when larvae were reared on three cultivated (tomato, eggplant and scarlet eggplant) and two wild solanaceae, jurubeba (Solanum paniculatum) and Solanum sp. Life table analysis were built to evaluate survival and growth of $N$. elegantalis populations feeding and developing on these host plants.

\section{Material and Methods}

\section{N. elegantalis rearing}

A laboratory colony of $N$. elegantalis was established from tomato fruits infested with larvae collected in Southeast Paraná State, Brazil in the municipality of Almirante Tamandaré ( $25^{\circ} 19^{\prime}$ ' $29^{\prime \prime} \mathrm{S}$; $49^{\circ} 18^{\prime} 36^{\prime \prime} \mathrm{W}$; $950 \mathrm{~m}$ asl), metropolitan region of Curitiba, southern Brazil. Periodically, collections of infested fruits with larvae were made in tomato crops for genetic renewal of the colony in the laboratory. These fruits were packed in polypropylene jars $(250 \mathrm{ml})$ lined with unsterilized absorbent paper, kept in a climatized chamber at $20 \pm 1{ }^{\circ} \mathrm{C}, 60 \pm 10 \%$ relative humidity, photoperiod 12:12. After completing the larval period, the larvae abandoned the fruits and pupated on the absorbent paper. The pupae were separated into groups of 15 in polypropylene containers $(250 \mathrm{ml})$.

After emergence, the adults were kept in wood cages $(40 \times 40 \times 60 \mathrm{~cm})$ with the sides covered with a nylonscreen. Food consisted of a $10 \%$ honey solution soaked in a cotton ball provided in plastic caps $5 \mathrm{~cm}$ diameter $\mathrm{x} 0.5 \mathrm{~cm}$ high. As a stimulus for oviposition, a green tomato fruit (20 to $30 \mathrm{~mm}$ diameter), was placed on a disk of absorbent paper lining the bottom of the cage. The food was changed daily, and the eggs collected and packed in $15 \times 5 \mathrm{~cm}$ polypropylene container lined with paper towel.

\section{Growing of cultivated and wild Solanaceae}

The hosts evaluated were grown in a greenhouse; the cultivated hosts were tomato cv. Coco Cherry, eggplant cv. Napoli and scarlet eggplant cv. Morro Grande. The seedlings were purchased in a commercial nursery seedling located in the Municipality of Almirante Tamandaré, Paraná state. For each treatment 10 pots of five liters capacity were prepared with substrate (Garden Plus ${ }^{\circledR}$ ); the seedlings were irrigated and fertilization was performed with chicken's manure at planting and cover (30 and 60 days). Forty-fifty fruits of Solanum sp. and $S$. paniculatum (jurubeba) were collected in the field and taken to the laboratory for the experiment.

Performance of the immature stages of $N$. elegantalis on different hosts When the fruiting period began, 80 unripe tomatoes were used, 20 eggplant fruits and 20 scarlet eggplant, 45 fruits of $S$. paniculatum and 50 fruits of Solanum sp. The fruits were immersed in water $+1 \%$ sodium hypochlorite for five minutes and rinsed for the removal of microorganisms. The fruits were individually placed on a paper towel disk; tomato, eggplant and scarlet eggplant were kept in $250 \mathrm{ml}$ polypropylene jars and the fruits of both Solanum species were kept in $15 \mathrm{ml}$ plastic containers. The small (up to $3 \mathrm{~cm}$ ) fruits of tomato, and both wild Solanum species were inoculated with one newly hatched larva of $N$. elegantalis and the large eggplant and scarlet eggplant fruits (above $10 \mathrm{~cm}$ ) received four larvae per fruit. All treatments were kept in a climatic chamber at $20 \pm 1^{\circ} \mathrm{C}$, relative humidity of $60 \pm 10 \%$ and photoperiod of 12: 12 hours until the end of the larval period. After leaving the fruits, pre-pupae were placed in $7 \times 4 \mathrm{~cm}$ plastic pots lined with paper towel until pupation. Pupae from each treatment were weighed; sexing was performed after adult emergence as described by Muñoz et al. (1991) and Carneiro et al. (1998). The sex ratio was calculated by the formula: $\mathrm{RS}=$ number of females $/$ number of males + females .

\section{Reproduction and longevity of $\mathrm{N}$. elegantalis on different hosts}

To evaluate the influence of the plant species consumed in the larval stage on adult traits, twenty replicates were tested for each host plant. Each replicate comprised one female/male pair kept in cylindrical plastic cages (10 cm diameter and $20 \mathrm{~cm}$ high), with the bottom lined with paper towel. Adults were fed on $10 \%$ honey solution diluted in distilled water provided in a cotton ball. To stimulate oviposition, a piece of host plant leaf $(5 \times 5 \mathrm{~cm})$ was placed between two superposed lids covering the cage; the lower lid had an opening $(4 \times 4 \mathrm{~cm})$ in the center to allow adults to make contact with the leaf inside the cage. The internal surface of the inner lid was lined with sulfite paper, where the eggs were laid, around the exposed host plant leaf. The eggs were counted daily and separated in plastic vials according to the female and oviposition date.

The effect of the larval food on the adult stage of $N$. elegantalis was evaluated on the longevity, duration of the pre-oviposition and oviposition periods, female fecundity and egg fertility estimated according to the formula (fertility*100/fecundity)

\section{Life table parameters}

Fertility life tables were constructed for each host plant to evaluate offspring performance. The reproductive parameters calculated were the net reproductive rate $\left(R_{0}\right)$, intrinsic rate of increase $(\mathrm{rm})$, finite rate of increase $(\lambda)$ and the duration of a generation $(T)$ The sex ratio used in the construction of the life tables was the one recorded for each host in the larval performance experiment: tomato $(0,50)$; eggplant $(0,40)$; scarlet eggplant $(0,60)$; . paniculatum $(0,64)$ e Solanum sp. $(0,52)$.

\section{Statistical analysis}

The effects of wild and cultivated solanaceous plants on $N$. elegantalis biology and reproduction were evaluated using analysis of variance (ANOVA). We used Tukey's test $(\mathrm{P}<0.05)$ to compare the hosts when significant differences were detected. When necessary, the data were transformed to $\log (\mathrm{x}+1)$ to comply with the normality assumptions and homogeneity of variances of Anova. The survival rate of egg-adult cycle was compared with chi-square test $(\mathrm{P}<0.05)$. All analyzes were performed using Statistica 7.0 software (Statsoft Inc., 2004).

\section{Results}

The development time of egg $\left(\mathrm{F}_{(4,220)}=268.47\right.$; p 0.001), larvae $\left(\mathrm{F}_{(4,220)}=88.48 ; \mathrm{p} 0.001\right)$, pre-pupa $\left(\mathrm{F}_{(4,220)}=38.86 ; \mathrm{p} 0.001\right)$, pupa $\left(\mathrm{F}_{(4,220)}=45.42 ; \mathrm{p} 0.001\right)$ pupal weight $\left(\mathrm{F}_{(4,220)}=31.10 ; \mathrm{p} 0.001\right)$ and 
Table 1

Average duration ( \pm SEM) of the immature stages (days), pupal weight $( \pm \mathrm{SE})(\mathrm{mg})$ and percentage of Neoleucinodes elegantalis survival when fed on different hosts in the larval stage. Temperature $20 \pm 1{ }^{\circ} \mathrm{C}$; relative humidity $60 \pm 10 \%$, photoperiod $12: 12 \mathrm{~h}$.

\begin{tabular}{|c|c|c|c|c|c|c|c|}
\hline Host & $\operatorname{Egg}^{1}$ (days) & $\operatorname{Larva}^{1}$ (days) & Pupa $^{1}$ (days) & Egg-adult $^{1}$ & Pupal weight ${ }^{1}$ (mg) & $\begin{array}{c}\text { Survival of } \\
\text { immatures }(\%)^{2}\end{array}$ & $\begin{array}{c}\text { Survival of } \\
\text { immatures }(\%)^{2}\end{array}$ \\
\hline Tomato & $5.8 \pm 0.03 c$ & $26.7 \pm 0.45 b c$ & $15.5 \pm 0.15 a$ & $48.2 \pm 0,4 b$ & $34.3 \pm 0.89 c$ & $69.0 a$ & $69.0 a$ \\
\hline Eggplant & $6.7 \pm 0.03 b$ & $37.3 \pm 0.45 a$ & $13.6 \pm 0.19 c$ & $57.9 \pm 0,4 a$ & $45.1 \pm 1,17 b$ & $49.0 \mathrm{~b}$ & $49.0 \mathrm{~b}$ \\
\hline Scarlet eggplant & $7.1 \pm 0.02 \mathrm{a}$ & $25.1 \pm 0.34 \mathrm{c}$ & $14.4 \pm 0.14 \mathrm{~b}$ & $46.4 \pm 0,3 c$ & $50.0 \pm 1.24 a$ & $71.0 \mathrm{a}$ & 71.0a \\
\hline Jurubeba & $7.0 \pm 0.09 a$ & $28.0 \pm 1.07 \mathrm{~b}$ & $14.3 \pm 0.35 b$ & $49.4 \pm 1,1 b$ & $34.2 \pm 1.55 c$ & $40.0 \mathrm{c}$ & $40.0 \mathrm{c}$ \\
\hline Solanum sp. & $7.1 \pm 0.06 a$ & $26.6 \pm 0.76 b c$ & $11.8 \pm 0.26 \mathrm{~d}$ & $45.5 \pm 0,68 c$ & $39.3 \pm 2.23 c$ & $49.0 \mathrm{~b}$ & $49.0 \mathrm{~b}$ \\
\hline
\end{tabular}

${ }^{1}$ Means followed by the same letters in columns did not differ significantly by Tukey's test ( $\left.P>0.05\right) ;{ }^{2}$ Survival percentages followed by the same letter do not differ according to the Chi-square method (P>0.05).

Table 2

Average duration ( \pm SE) of pre-oviposition and oviposition periods, number of eggs per female and fertility of Neoleucinodes elegantalis fed on wild and cultivated hosts during the larval stage. Temperature: $20 \pm 1^{\circ} \mathrm{C}$; relative humidity: $60 \pm 10 \%$ and photoperiod: 12:12 hours L:D.

\begin{tabular}{|c|c|c|c|c|c|}
\hline Host & Couples $(\mathrm{N})^{* *}$ & Pre oviposition (days) & Oviposition (days) & Eggs/female (N) & Viability (\%) \\
\hline Tomato & $20(15)$ & $5.5 \pm 0.28 b$ & $5.4 \pm 0.31 \mathrm{ab}$ & $70.9 \pm 18,5 b$ & $79.7 \pm 6.79$ \\
\hline Eggplant & $17(14)$ & $5.2 \pm 0.17 b$ & $5.1 \pm 0.29 a b$ & $148.6 \pm 41,8 a$ & $87.0 \pm 2.32$ \\
\hline Scarlet eggplant & $20(16)$ & $8.2 \pm 0.89 a$ & $2.0 \pm 0.16 c$ & $45.6 \pm 11,1 c$ & $80.7 \pm 3.32$ \\
\hline Jurubeba & $6(6)$ & $5.9 \pm 0.59 b$ & $3.8 \pm 0.40 b c$ & $39.8 \pm 23,5 c$ & $71.9 \pm 6.38$ \\
\hline Solanum sp. & $13(10)$ & $5.4 \pm 0.26 b$ & $6.3 \pm 0.42 a$ & $80.7 \pm 24,6 b$ & $60.9 \pm 9.11$ \\
\hline
\end{tabular}

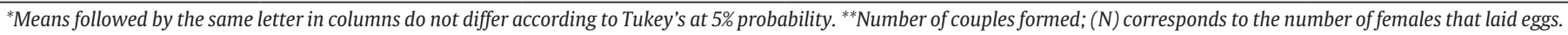

egg-adult cycle $\left(\mathrm{F}_{(4,220)}=82.96 ; \mathrm{p} 0.001\right)$ were significantly influenced by the host plant (Table 1 ). After 24 hours, larval entrance holes into the fruits were observed in all hosts and no mortality of larvae outside the fruits were observed, indicating that the texture and rigidity of the skin surface of the hosts do not affect the penetration of the neonate larvae.

The larval stage was significantly longer (37,3 days) when feeding on eggplant fruits whereas the pupal stage was longest (15.5 days) on tomato in comparison to the other hosts. The development from egg to adult was completed on all hosts and lasted less than 50 days at $20^{\circ} \mathrm{C}$, except on eggplant where development from egg to adult was statistically longer (57.9 days) than on the other hosts (Table 1). Differences recorded on development time of $N$. elegantalis are due to the quality of the larval food (Awmack and Leather, 2002; Holmes et al., 2020). Percent survival was significantly higher on tomato (69\%) and scarlet eggplant (71\%) in relation to the other treatments, all with less than $50 \%$ survival (Table 1 ).

The number of adult pairs formed varied according to the number of insects reaching the adult stage in each host, as well as to the number of ovipositing females (Table 2). Due to the low survival of the immatures reared on jurubeba ( $S$. paniculatum) fruits, only six couples could be formed in this treatment. The pre-oviposition period $\left(\mathrm{F}_{(4,201)}=8.05\right.$; p 0.001), oviposition $\left(F_{(4,201)}=17.38 ; \mathrm{p} 0.001\right)$ and number of eggs per female $\left(\mathrm{F}_{(4,56)}=2.73 ; \mathrm{P}<0,037\right)$ were significantly influenced by the host plant (Table 2). Larvae fed on scarlet eggplant produced adults with the longest preoviposition period (8.2 days), and females in this treatment laid eggs for only two days, indicating the negative effect of this food on the fecundity of $N$. elegantalis (Table 2). The highest mean number of eggs were laid by females reared in the larval stage on eggplant (148.6 eggs/female) while the lowest one was recorded for females fed on jurubeba during the larval stage (39.8 eggs/female) (Table 2).

Both males and females lived longer than 13 days in all treatments showing that the larval food did not significantly affect the longevity of females $\left(\mathrm{F}_{(4,71)}=0.80 ; \mathrm{P}=0.528\right)$ and males $\left(\mathrm{F}_{(4,71)}=0.34, \mathrm{P}=0.844\right)$ of $N$. elegantalis (Table 3 ).

The life table analysis showed that the highest net reproductive rate $\left(R_{0}\right)$ was recorded for insects reared on eggplant and the lowest one in jurubeba (Table 4). The duration of a generation was influenced by the host plant and ranged from 44.4 days in scarlet eggplant to 57.6 days in eggplant. The $\mathrm{r}_{\mathrm{m}}$ of the three cultivated hosts remained stable (0.055).
Table 3

Mean longevity $( \pm \mathrm{SE}$ ) of males and females of Neoleucinodes elegantalis reared on different hosts during the larval stage. Temperature $20 \pm 1{ }^{\circ} \mathrm{C}$; relative humidity, $60 \pm 10 \%$ and photoperiod $12: 12$ hours L:D.

\begin{tabular}{cccc}
\hline \multirow{2}{*}{ Host } & Couples & \multicolumn{2}{c}{ Longevity (days) ${ }^{\mathrm{NS}}$} \\
\cline { 2 - 4 } & $(\mathrm{N})$ & Females & Males \\
\hline Tomato & 20 & $16.9 \pm 0.77$ & $14.2 \pm 1.05$ \\
Eggplant & 20 & $16.2 \pm 1.17$ & $13.8 \pm 1.08$ \\
Scarlet eggplant & 17 & $14.5 \pm 1.85$ & $13.2 \pm 1.46$ \\
Jurubeba & 13 & $15.5 \pm 2.43$ & $15.7 \pm 2.04$ \\
Solanum sp. & 6 & $13.8 \pm 1.42$ & $13.2 \pm 1.16$ \\
\hline
\end{tabular}

NS - mean values for males and females are not significantly different according to Tukey's test at 5\% probability.

The finite rate of increase $(\lambda)$, which indicates the number of females that are added to the population at each generation did not differ among the hosts evaluated (Table 4).

\section{Discussion}

The biological parameters of $N$. elegantalis feeding on wild hosts in the larval stage showed that both uncultivated Solanum species are able to sustain its population, since the development cycle, reproduction and survival to produce a second generation were successfully achieved on these hosts. Females laid fertile eggs in all treatments, and egg viability was not significantly affected by the host plants evaluated.

There is no reference in the literature on the potential of uncultivated Solanum plants to sustain the development and reproduction of $N$. elegantalis. Previous results on tomato and other cultivated solanaceous species showed that development time, survival rate and fertility are similar to the ones recorded in the present study (Fernández and Salas, 1985; Marcano, 1991a, 1991b; Muñoz et al., 1991; Noboa and Viera, 2020). However, data obtained from the fertility life table of $N$. elegantalis varied depending on the host species used; the intrinsic growth rate $\left(\mathrm{r}_{\mathrm{m}}\right)$ is the main parameter obtained from fertility life tables (Pedigo and Zeiss, 1996) and according to Andrewartha and Birch (1954) as the value of $r_{m}$ increases, the more successful will be the species in a given environment. The $\mathrm{r}_{\mathrm{m}}$ of $N$. elegantalis 
Table 4

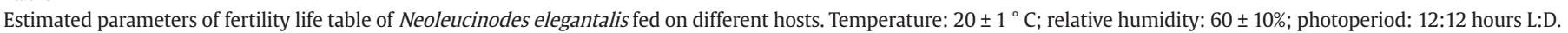

\begin{tabular}{|c|c|c|c|c|}
\hline Host & Reproductive rate $\left(R_{0}\right)$ & Generation time $(\mathrm{T})$ & Intrinsic growth rate $\left(\mathrm{r}_{\mathrm{m}}\right)$ & Finite rate of increase $(\lambda)$ \\
\hline Tomato & 17.22 & 52.7 & 0.054 & 1.06 \\
\hline Eggplant & 22.43 & 57.6 & 0.054 & 1.06 \\
\hline Scarlet eggplant & 11.44 & 44.4 & 0.055 & 1.06 \\
\hline Jurubeba & 10.20 & 50.5 & 0.046 & 1.05 \\
\hline Solanum sp. & 14.62 & 45.4 & 0.059 & 1.06 \\
\hline
\end{tabular}

developing on the wild species of Solanum sp. (0.059) showed that this was the most suitable host for population growth, while the other wild host, jurubeba (0.046) was the least suitable one. These results are useful to indicate the performance of the species on wild and cultivated hosts and the most suitable ones for the development and reproduction of $N$. elegantalis. The lengthening of development time and reduction in fertility are indications that the diet does not meet the insects' nutritional needs (Awmack and Leather, 2002). According to these parameters, the less suitable wild host for $N$. elegantalis was jurubeba while scarlet eggplants was the cultivated host least accepted by the species.

Tomatoes are the most attacked cultivated host by $N$. elegantalis (Miranda et al., 2005; Boiça Júnior et al., 2007; Benvenga et al., 2010; Arcanjo et al., 2021). The occurrence of successive tomato blooming favors the continuous availability of fruits to the larvae. The yield losses in tomato are estimated between 79\% (Miranda et al., 2005) and 90\% (Carneiro et al., 1998; Silva et al., 2019a, 2019b) which shows the good adaptation of $N$. elegantalis to this host. In scarlet eggplant, larvae of $N$. elegantalis were found drilling down the fruits and leaving them completely hollow, causing severe direct economic losses to the production (Picanço et al., 1997).

Oligophagy allows the simultaneous development of the tomato fruit borer on different hosts and provide a succession of cultivated and uncultivated hosts throughout the seasons (Fitt, 1989). According to EPPO (2014), N. elegantalis does not seem to enter diapause, indicating that the species requires alternative hosts to survive during adverse conditions or in the absence of preferential hosts in subtropical and temperate regions. Díaz-Montilla et al.(2013) reported five cultivated and 10 wild solanaceous species hosting $N$. elegantalis which are important for the maintenance of this pests. As reported by Silva et al. (2017a), $S$. lycopersicum cultivation is expanding into previously uncultivated areas and its introduction and establishment into new areas may well be only a matter of time. The occurrence and abundance of $N$. elegantalis depends directly on climatic factors (Silva et al., 2020); temperature has a significant effect on the density of $N$. elegantalis in the field; while in the tropical areas of Brazil, tomatoes are subjected to borer attack throughout the year, in the subtropical southern part of the country, tomato cultivation is restricted between September and March (spring and summer) (Moraes and Foerster, 2015). Since $N$. elegantalis does not enter diapause (EPPO, 2015), the species must rely on alternative hosts during autumn and winter when no tomato is grown in subtropical and temperate areas.

Our results show that both wild Solanum species and the other cultivated crops provide a continuous source of $N$. elegantalis in the absence of tomato crops in the field. Moreover, jurubeba and Solanum sp. may be used as shelter for the pest when insecticide applications are carried out on the cultivated crops, or as overwintering hosts. On the other hand, wild solanaceous species may provide refuge for natural enemies and thus should be considered in pest management strategies of N. elegantalis; however, Plaza et al. (1992) argue that due to the short time spent by larvae on the fruits' surface before penetrating them, the natural biological control of $N$. elegantalis is inefficient and no more than $2 \%$ of larval mortality takes place outside the fruits. Other authors however, favor the conservation of natural enemies (Berti and Marcano, 1991; Picanço et al., 2007). Egg parasitoids may also contribute to the control of $N$. elegantalis and thus refuge areas may be important for their preservation when unfavorable conditions prevail within the crop. Blackmer et al. (2001) reported an increase in the rate of parasitism by Trichogramma pretiosum (Hymenoptera: Trichogrammatidae) on eggs of $N$. elegantalis from 2.4 to $28.7 \%$ at the end of the tomato crop, when insecticide use had decreased.

Chemical control of $N$. elegantalis is hampered by the larval habit of penetrating the fruits soon after hatching (Fragoso et al., 2021), and alternative methods should be sought for the management of the pest. Arcanjo et al. (2021) developed a decision-making system for the management of $N$. elegantalis, based on sequential sampling plans for eggs, according to insecticide spraying methods and tomato plant stages. Fragoso et al. (2021) evaluated the activity of four plant extracts on different stages of $N$. elegantalis, of which only aqueous extracts of commercial rope tobacco Nicotiana tabacum showed insecticidal activity. In Colombia, four distinct races of $N$. elegantalis associated to the different larval hosts were recorded (Díaz-Montilla et al., 2018); the authors suggest that these hybrids can be potentially useful for the management of $N$. elegantalis, since they showed reproductive incompatibility which resulted in low survival rates and consequently low densities in the field. The large variety of host plants that sustain the development and reproduction of $N$. elegantalis plays an important role in its management, together with chemical, genetic and ecological practices.

Finally, our results showed that the biological traits of the small tomato fruit borer developing on a wide spectrum of solanaceous plants emphasizes the potential of the species to become an invasive species to tomato-producing countries. However much remains to be investigated to understand the ecological role of these hosts on the management of the tomato fruit borer in tomato crops.

\section{Acknowledgements}

This study was supported by fellowships provided to the authors by the Coordination for the Improvement of Higher Education Personnel (CAPES) (CPM) and the National Council for Scientific and Technological Development (CNPq) (LAF)

\section{Conflicts of interest}

There was no conflict of interest regarding the preparation and submission of this manuscript.

\section{Author contribution statement}

CP Moraes conducted the experiments and LA Foerster was responsible for the experimental design and wrote the paper. Both authors read and approved the manuscript 


\section{References}

Andrewartha, H. G., Birch, L. C., 1954. The innate capacity for increase in numbers. In: Andrewartha, H.G., Birch, L.C. (Eds.), The Distribution and Abundance of Animals. University of Chicago Press, Chicago, pp. 31-54.

Arcanjo, L. P., Silva, É. M., Araújo, T. A., Crespo, A. L. B., Santana Júnior, P. A., Oliveira Gomes, G. B., Picanço, M. C., 2021. Decision-making systems for management of the invasive pest Neoleucinodes elegantalis(Guenée) (Lepidoptera: Crambidae) in commercial tomato crops according to insecticide spray method and plant stage. Crop Prot. 140, 105408. http://dx.doi.org/10.1016/j.cropro.2020.105408.

Awmack, C. S., Leather, S. R., 2002. Host plant quality and fecundity in herbivorous insects. Annu. Rev. Entomol. 47 (1), 817-844. http:// dx.doi.org/10.1146/annurev.ento.47.091201.145300.

Barbuceanu, D., Dobrescu, M. C., Boruz, V., Timus, A., 2015. Host plant and climatic preferences of the invasive species Metcalfa pruinosa (Say, 1830) (Hemiptera: flatidaein some places from southern Romania. Curr. Trends Nat. Sci. 4, 13-22.

Benvenga, S. R., Bortoli, S. A. D., Gravena, S., Barbosa, J. C., 2010. Monitoramento da broca-pequena-do-fruto para tomada de decisão de controle em tomateiro estaqueado. Hortic. Bras. 28 (4), 435-440. http://dx.doi.org/10.1590/S0102-05362010000400010.

Berti, J., Marcano, R., 1991. Preferência de Trichogramma pretiosum Riley (Hymenoptera: Trichogrammatidae) por huevos de diferentes edades de vários hospederos. Bol. Entomol. Venez. 6, 77-81.

Biondi, A., Guedes, R. N. C., Wan, F.-H., Desneux, N., 2018. Ecology, worldwide spread, and management of the invasive South American tomato pinworm Tuta absoluta: past, present and future. Annu. Rev. Entomol. 63 (1), 239-258. http://dx.doi.org/10.1146/annurevento-031616-034933.

Blackmer, J. L., Eiras, A. E., Souza, C. L. M., 2001. Oviposition preference of Neoleucinodes elegantalis (Guenée) (Lepidoptera: Crambidae) and rates of parasitism by Trichogramma pretiosum Riley (Hymenoptera: Trichogrammatidae) on Lycopersicon esculentum in São José de Ubá, RJ, Brazil. Neotrop. Entomol. 30 (1), 89-95. http://dx.doi. org/10.1590/S1519-566X2001000100014.

Boiça Júnior, A. L., Macedo, M. A. A., Torres, A. L., Angelini, M. R., 2007. Late pest control in determinate tomato cultivars. Sci. Agric. 64 (6), 589-594. http://dx.doi.org/10.1590/S0103-90162007000600005.

Camerini, G., 2017. Spiders (Araneae) as predators of the exotic Metcalfa pruinosa (Say, 1830) Homoptera: Flatidae) in the central western Po floodplain (Northern Italy). Indian J. Arachnology. 6, 72-80.

Carneiro, J. S., Haji, F. N. P., Santos, F. A. M., 1998. Bioecologia e controle da broca-pequena-do-tomateiro Neoleucinodes elegantalis. Embrapa Meio-Norte, Teresina, 14 pp. (Circular, 26).

Desneux, N., Wajnberg, E., Wyckhuys, K. A. G., Burgio, G., Arpaia, S., Narvaez-Vasquez, C. A., González-Cabrera, J., Catalán Ruescas, D., Tabone, E., Frandon, J., Pizzol, J., Poncet, C., Cabello, T., Alberto Urbaneja, A., 2010. Biological invasion of European tomato crops by Tuta absoluta: ecology, geographic expansion and prospects for biological control. J. Pest Sci. 83 (3), 197-215. http://dx.doi. org/10.1007/s10340-010-0321-6.

Desneux, N., Luna, M. G., Guillemaud, T., Urbaneja, A., 2011. The invasive South American tomato pinworm, Tuta absoluta, continues to spread in Afro-Eurasia and beyond: the new threat to tomato world production. J. Pest Sci. 84 (4), 403-408. http://dx.doi.org/10.1007/ s10340-011-0398-6.

Díaz-Montilla, A. E., Baena-Bejarano, N., Saldamando, C. I., MontoyaLerma, J., 2018. Reproductive incompatibility and fitness components in Neoleucinodes elegantalis races (Lepidoptera, Crambidae) from three Solanaceae hosts. Caldasia 40 (2), 199-215. http://dx.doi. org/10.15446/caldasia.v40n2.67241.

Díaz-Montilla, A. E., Solis, M. A., Kondo, T., 2013. The tomato fruit borer Neoleucinodes elegantalis (Guenée) (Lepidoptera: Crambidae) an insect pest of neotropical solanaceous fruits. In: Peña, J.E. (Ed.), Potential Invasive Pests of Agricultural Crops. CAB International, Wallingford, pp. 137-159. http://dx.doi.org/10.1079/9781845938 291.0137.

European and Mediterranean Plant Protection Organization - EPPO, 2014. Pest Risk Analysis for Neoleucinodes elegantalis. EPPO, Paris, 54 pp.

European and Mediterranean Plant Protection Organization - EPPO, 2015. Neoleucinodes elegantalis (Lepidoptera: Crambidae). Bull. OEPP 45, 9-13. https://doi.org/10.1111/epp.12189.

Fernández, S., Salas, J., 1985. Estúdios sobre la biologia del perfurador del tomate Neoleucinodes elegantalis Guenée (Lepidoptera: pyraustidae). Agron. Trop. 35, 77-82.

Fand, B. B., Shashank, P. R., Suroshe, S. S., Chandrashekar, K., Meshram, N. M., Timmanna, H. N., 2020. Invasion risk of the South American tomato pinworm Tuta absoluta(Meyrick) (Lepidoptera: Gelechiidae) in India: predictions based on MaxEnt ecological niche modelling. Int. J. Trop. Insect Sci. 40 (3), 561-571. http://dx.doi.org/10.1007/ s42690-020-00103-0.

Fitt, G. P., 1989. The ecology of Heliothis species in relation to agroecosystems. Annu. Rev. Entomol. 34 (1), 17-52. http://dx.doi. org/10.1146/annurev.en.34.010189.000313.

Fragoso, D. F. M., Túler, A. C., Pratissoli, D., Carvalho, J. R., Valbon, W. R., Queiroz, W. T., Pinheiro, P. F., Costa, A. V., Bueno, R. C. O. F., 2021. Biological activity of plant extracts on the small tomato borer Neoleucinodes elegantalis, an important pest in the Neotropical region. Crop Prot. 145, 105606. http://dx.doi.org/10.1016/j. cropro.2021.105606.

Goergen, G., Kumar, P. L., Sankung, S. B., Togola, A., Tamò, M., 2016. First report of outbreaks of the fall armyworm Spodoptera frugiperda (J.E. Smith) (Lepidoptera, Noctuidae), a new alien invasive pest in West and Central Africa. PLoS One 11 (10), 10. http://dx.doi.org/10.1371/ journal.pone.0165632.

Holmes, L. A., Nelson, W. A., Lougheed, S. C., 2020. Food quality effects on instar-specific life histories of a holometabolous insect. Ecol. Evol. 10 (2), 626-637. http://dx.doi.org/10.1002/ece3.5790.

Marcano, R. V., 1991a. Estudio de la biologia y algunos aspectos del comportamento del perforador del fruto del tomate Neoleucinodes elegantalis (Lepidoptera: Pyralidae) en tomate. Agron. Trop. 41, 257-263.

Marcano, R. V., 1991b. Ciclo biologico del perfurador del fruto del tomate Neoleucinodes elegantalis (Guenée) (Lepidoptera: Pyralidae), usando berenjena (Solanum melongena) como alimento. Bol. Entomol. Venezoelana 6, 135-141.

Miranda, M. M. M., Picanço, M. C., Zanuncio, J. C., Bacci, L., Silva, E. M., 2005. Impact of integrated pest management on the population of leaf miners, fruit borers, and natural enemies in tomato. Cienc. Rural 35 (1), 204-208. http://dx.doi.org/10.1590/S0103-84782005000100033.

Moraes, C. P., Foerster, L. A., 2014. Development and reproduction of Neoleucinodes elegantalis (Lepidoptera: Crambidae) on tomato (Solanum licopercum) cultivars. Rev. Colomb. Entomol. 40, 40-43.

Moraes, C. P., Foerster, L. A., 2015. Thermal requirements, fertility, and number of generations of Neoleucinodes elegantalis (Guenée) (Lepidoptera: crambidae). Neotrop. Entomol. 44 (4), 338-344. http://dx.doi.org/10.1007/s13744-015-0293-6.

Muñoz, L. E., Serrano, A. P., Pulido, J. I., De La Cruz, J. L., 1991. Ciclo de vida y enemigos naturales de Neoleucinodes elegantalis (Guenée) (Lepidoptera: Pyralidae) passador del fruto del lulo Solanum quitoense Lam. en el Valle del Cauca. Acta Agron. 41, 99-104. 
Noboa, M., Viera, W., 2020. Biology of Neoleucinodes elegantalis (Guenée 1854) (Lepidoptera:Crambidae): pest of economic importance of naranjilla,an Amazonian fruit of Ecuador. Int. J. Trop. Insect Sci. 40 (3), 717-722. http://dx.doi.org/10.1007/s42690-020-00118-7.

Pedigo, L. P., Zeiss, M. R., 1996. Developing a degree-day model for predicting insect development. In: Pedigo, L.P., Zeiss, M. R. (Eds.), Analyses in Insect Ecology and Management. Iowa State University Press, Ame, p. 67-74.

Picanço, M. C., Bacci, L., Crespo, A. L. B., Miranda, M. M. M., Martins, J. C., 2007. Effect of integrated pest management practices on tomato production and conservation of natural enemies. Agric. For. Entomol. 9, 327-335.

Picanço, M. C., Casali, V. W. D., Leite, G. L. D., Oliveira, I. R., 1997. Lepidópteros associados ao jiloeiro. Hortic. Bras. 15, 112-114.

Picanço, M. C., Leite, G. L. D., Guedes, R. N. C., Silva, E. A., 1998. Yield loss in trellised tomato affected by insecticidal sprays and plant spacing. Crop Prot. 17 (5), 447-452. http://dx.doi.org/10.1016/ S0261-2194(98)00040-4.

Plaza, A. S., Leon, E. M., Fonseca, J. P., De La Cruz, J., 1992. Biology, behaviour and natural enemies of Neoleucinodes elegantalis (Guenée). Rev. Colomb. Entomol. 18, 31-37.

Silva, R. S., Kumar, L., Shabanib, F., Picanço, M. C., 2017a. Potential risk levels of invasive Neoleucinodes elegantalis (small tomato borer) in areas optimal for open-field Solanum lycopersicum (tomato) cultivation in the present and under predicted climate change. Pest Manag. Sci. 73 (3), 616-627. http://dx.doi.org/10.1002/ps.4344.

Silva, R. S., Marques, A. E., Ferreira, D. O., Costa, A. H., Ribeiro, A. V., Oliveira, M. G. A., Meira, R. M. S. A., Pereira, L. J., Picanço, M. C., 2017b. Neoleucinodes elegantalis (Lepidoptera: Crambidae): an organism invisible to the defences of tomato fruits. Ann. Appl. Biol. 170 (3), 348-356. http://dx.doi.org/10.1111/aab.12335.

Silva, E. M., Crespo, A. L. B., Farias, E. S., Bacci, L., Queiroz, R. B., Picanço, M. C., 2019a. Conventional sampling plan for scouting Neoleucinodes elegantalis (Lepidoptera: Crambidae) eggs on tomato fruits. J. Econ. Entomol. 112 (5), 2433-2440. http://dx.doi.org/10.1093/jee/toz158. Silva ÉM, Silva RS, Silva LJ, Costa Gontijo P, Silva Galdino TV, Picanço MC, et al., 2019b. Seasons of the year affect critical stage and key mortality factors for Neoleucinodes elegantalis in open field tomatoes. Annals of Applied Biology. 174(2):133-141. http://dx.doi. org/10.1111/aab.12479.

Silva, É. M., Silva, R. S., Gontijo, P. C., Rosado, J. F., Bacci, L., Martins, J. C., Picanço, M. C., 2020. Climatic variables limit population abundance of Neoleucinodes elegantalis: important neotropical tomato pest. Crop Prot. 138, 105325. http://dx.doi.org/10.1016/j. cropro.2020.105325.

Statsoft Inc., 2004. Statistica for Windows, Statsoft Inc., Tulsa, OK.

Zucchi, R. A., Silveira Neto, S., Nakano, O., 1993. Guia de identificação de pragas agrícolas. FEALQ Piracicaba, 139 pp. 